\title{
UJI FITOKIMIA DAN AKTIVITAS ANTIBAKTERI FRAKSI ETIL ASETAT, KLOROFORM DAN PETROLEUM ETER EKSTRAK METANOL ALGA COKLAT Sargassum vulgare DARI PANTAI KAPONG PAMEKASAN MADURA
}

\author{
Siti Khoiriyah, Ahmad Hanapi, A. Ghanaim Fasya \\ Jurusan Kimia, Fakultas Sains dan Teknologi, UIN Maulana Malik Ibrahim Malang
}

\begin{abstract}
Based on the Allah's decree in surah An Nahl verse 14, Allah SWT given His pleasants such seas and its contents for human being so as to thankfully for His sakes. Biological varieties like algae need to be used by its existences. One kind of algae species was brown algae called Sargassum vulgare. The purposes of this research were to conduct fraction which given highest antibacterial activity toward Staphylococcus aureus and Escherichia coli bacteria. Besides that, this study attempt to identify the active compound that contained in fraction which gives the highest antibacterial activity.

Kind of brown algae Sargassum vulgare is macerated to methanol then the methanol extract is hydrolyzed with $\mathrm{HC1} 2 \mathrm{~N}$ catalyst and neutralized to NaHCO3. The result of hydrolyze partitioned to etil acetate, chloroform and petroleum ether. The chosen organic layer is tested its antibacterial activities using disk diffusion methods toward Staphylococcus aureus and Escherichia coli bacteria with extract concentration 0,$5 ; 1$; 2,5; 5: 7,5 and $10 \%$. The fraction which gives highest antibacterial activity will be identifying its compound category using reagent test (phytochemical) then separated with thick layer of chromatography analytic (TLC).

The result of this research showed that fraction which can bring highest antibacterial activity was etil acetate. The highest antibacterial activity obtained by the most high concentration $10 \%$, with zone of inhibitionare $8,5 \mathrm{~mm}$ towards Staphylococcus aureus and $6 \mathrm{~mm}$ towards Escherichia coli bacteria. According to phytochemical test result, it showed the active compound group that already existed in etil acetate fraction is steroid. Based on segregation using thick layer chromatography analytics, it is acquired 6 spots which categorized in steroid compound.
\end{abstract}

Keywords: Antibacterial, fraction, brown algae Sargassum vulgare.

\section{ABSTRAK}

Berdasarkan firman Allah SWT QS an Nahl ayat 14, Allah SWT telah memberikan nikmatNya berupa lautan beserta isinya agar manusia dapat bersyukur. Keragaman hayati dari laut berupa alga perlu dimanfaatkan keberadaannya. Salah satunya adalah alga coklat jenis Sargassum vulgare. Penelitian ini bertujuan untuk mengetahui fraksi pelarut yang memberikan aktivitas antibakteri tertinggi terhadap bakteri Staphylococcus aureus dan Escherichia coli serta untuk mengidentifikasi golongan senyawa aktif yang terkandung dalam fraksi pelarut yang memberikan aktivitas antibakteri tertinggi.

Alga coklat $S$. vulgare dimaserasi dengan metanol kemudian ekstrak metanol yang diperoleh dihidrolisis dengan katalis $\mathrm{HCl} 2 \mathrm{~N}$ dan dinetralkan dengan $\mathrm{NaHCO}_{3}$. Ekstrak hasil hidrolisis dipartisi dengan etil asetat, kloroform, dan petroleum eter. Lapisan organik yang diperoleh kemudian diuji aktivitas antibakterinya menggunakan metode difusi cakram terhadap bakteri $S$. aureus dan E. coli dengan konsentrasi ekstrak 0,$5 ; 1 ; 2,5 ; 5 ; 7,5$ dan $10 \%$. Fraksi pelarut yang memberikan aktivitas antibakteri tertinggi diidentifikasi golongan senyawanya menggunakan uji reagen (fitokimia) kemudian dipisahkan dengan kromatografi lapis tipis analitik.

Hasil penelitian menunjukkan bahwa fraksi pelarut yang memberikan aktivitas antibakteri tertinggi adalah etil asetat. Aktivitas antibakteri terbaik diperoleh pada konsentrasi ekstrak paling tinggi yaitu $10 \%$ dengan zona hambat $8,5 \mathrm{~mm}$ terhadap bakteri $S$. aureus dan $6 \mathrm{~mm}$ terhadap bakteri E. coli. Berdasarkan uji fitokimia diketahui bahwa golongan senyawa yang terkandung dalam fraksi etil asetat adalah steroid. Berdasarkan pemisahan menggunakan KLTA diperoleh 6 spot yang merupakan golongan senyawa steroid.

Kata Kunci: Antibakteri, fraksi, alga coklat Sargassum vulgare. 


\section{PENDAHULUAN}

Allah SWT menciptakan segala sesuatu di bumi ini dengan manfaatnya masing-masing, salah satunya adalah laut dan segala sesuatu yang ada di dalamnya. Pemanfaatan hasil laut tidak hanya berupa ikan, namun masih banyak mahluk hidup lainnya yang dapat dimanfaatkan keberadaannya. Sebagaimana firman Allah SWT dalam surat an Nahl ayat 14 :

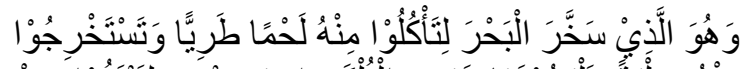

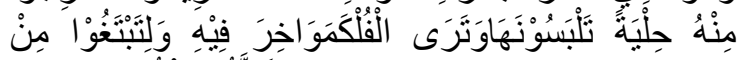

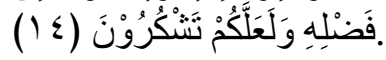

"Dan Dia-lah, Allah yang menundukkan lautan (untukmu), agar kamu dapat memakan daripadanya daging yang segar (ikan), dan kamu mengeluarkan dari lautan itu perhiasan yang kamu pakai, dan kamu melihat bahtera berlayar padanya, dan supaya kamu mencari (keuntungan) dari karuniaNya, dan supaya kamu bersyukur" (QS. an Nahl : 14).

Makna sakhkhara al-bahra menjelaskan bahwa Allah SWT telah memberikan nikmatNya yang ada di laut kepada hamba-hambaNya, sehingga memungkinkan bagi hamba-hambaNya untuk mengambil manfaat. Sebagaimana dalam ayat tersebut Allah SWT telah memerintahkan untuk memakan (lii ta'kulu), mengeluarkan (tastakhriju), melihat (wa taraa) dan mencari (li tabtaghu) keuntungan dari karuniaNya yang sudah ada di laut agar dapat mensyukuri segala nikmat dan karunia berupa luasnya lautan beserta isinya.

Salah satu potensi biota laut perairan Indonesia adalah rumput laut yang secara taksonomi dikelompokkan ke dalam divisiThallophyta.Berdasarkan penelitian sebelumnya diketahui bahwa alga berpotensi sebagai antivirus, antibakteri, antijamur, antitumor dan antioksidan.

Adanya penelitian yang menguji bioaktivitas suatu bahan alam sebagai obat khususnya antibakteri mempunyai tujuan penting, yaitu untuk mengurangi penggunaan bahan kimia yang berakibat pada resistensi obat. Penggunaan suatu bahan alam sebagai obat antibakteri alami memiliki kelebihan dibandingkan dengan obat antibakteri sintesis. Hal ini dikarenakan mudah didapat dan efek samping yang ditimbulkan terhadap kesehatan umumnya relatif kecil.

Ekstrak alga coklat jenis Sargassum menunjukkan kemampuan menghambat pertumbuhan yang maksimal terhadap beberapa jenis bakteri patogen seperti Pseudomonas aeruginosa, Sthapylococcus aureus, Salmonella typhii, dan Escherichia coli, dimana hal tersebut dapat diketahui setelah dilakukan suatu percobaan secara in vitro (Sastry dan Rao, 1994 dalam Alamsjah, 2011). Alga coklat Sargassum sp. memiliki kandungan $\mathrm{Mg}$, $\mathrm{Na}, \mathrm{Fe}$, tanin, iodin dan fenol yang berpotensi sebagai bahan antimikroba terhadap beberapa jenis bakteri patogen yang dapat menyebabkan diare (Sastry dan Rao, 1994 dalam Bachtiar, dkk., 2012).

Salah satu jenis bakteri yang merugikan manusia adalah bakteri $E$. coli dan S. aureus. Bakteri E.coli adalah kuman yang banyak ditemukan di usus besar manusia, akan tetapi kontaminasinya dapat menyebabkan diare. Organisme ini menjadi patogen bila mencapai jaringan di luar saluran pencernaan (usus) khususnya saluran air kemih, saluran empedu, dan paru-paru (Jawetz, et al., 1996). Bakteri $S$. aureus dapat mengakibatkan infeksi pada kulit atau luka pada organ tubuh jika bakteri inimengalahkan mekanisme pertahanan tubuh.

Beberapa penelitian tentang pengujian aktivitas antibakteri telah banyak dilakukan. Uji antibakteri alga merah jenis Eucheuma spinosum menghasilkan daya hambat tertinggi sebesar $6 \mathrm{~mm}$ dan $5,5 \mathrm{~mm}$ pada pelarut petroleum eter, $4 \mathrm{~mm}$ dan $3 \mathrm{~mm}$ pada pelarut etil asetat, $3 \mathrm{~mm}$ dan $2,5 \mathrm{~mm}$ pada pelarut kloroform terhadap bakteri E. coli dan S. aureus (Miftahurrohmah, 2012). 
Penggunaan pelarut metanol menghasilkan zona hambat 3,5 $\mathrm{mm}$ dan $1,3 \mathrm{~mm}$ terhadap bakteri yang sama pada alga jenis Eucheuma cottoni (Muhimmah, 2013).

Adanya aktivitas antibakteri dari suatu bahan alam tentunya dipengaruhi oleh kandungan senyawa metabolit sekunder yang berada di dalamnya. Senyawa metabolit sekunder yang diduga mempunyai aktivitas antibakteri adalah golongan steroid (Alfiyaturohmah, 2013).

Berdasarkan penelitian yang dilakukan oleh Alfiyaturohmah (2013), diketahui bahwa ekstrak kasar alga coklat $S$. vulgare mempunyai aktivitas antibakteri tertinggi pada pelarut kloroform dengan konsentrasi ekstrak $1 \%$ dan $10 \%$. Zona hambat yang dihasilkan sebesar 1,6 mm pada bakteri $E$. coli dan $1,8 \mathrm{~mm}$ pada bakteri $S$. aureus. Aktivitas tersebut masih tergolong lemah karena zona hambat yang dihasilkan kurang dari $5 \mathrm{~mm}$ (Yuningsih, 2007).

Miftahurrahmah (2012) melakukan uji aktivitas antibakteri alga merah jenis $E$. spinosum dengan metode maserasi menggunakan pelarut metanol dan hidrolisis kemudian dipartisi dengan variasi pelarut yang berbeda kepolarannya. Dari penelitian tersebut diketahui bahwa aktivitas antibakteri ekstrak yang telah dihidrolisis lebih besar dibandingkan dengan ekstrak kasar sebelum dihidrolisis. Zona hambat ekstrak hasil hidrolisis fraksi petroleum eter terhadap bakteri $E$. coli adalah $6 \mathrm{~mm}$ dan ekstrak metanol (sebelum dihidrolisis) adalah $3 \mathrm{~mm}$. Sedangkan aktivitas terhadap bakteri $S$. aureus adalah 5,5 $\mathrm{mm}$ untuk fraksi petroleum eter dan 4 $\mathrm{mm}$ untuk pelarut metanol (sebelum dihidrolisis).

Menurut Tensiska, dkk. (2007) pada reaksi hidrolisis akan terjadi pemutusan hemiasetal dalam komponen glikon (polar/terikat gula) sehingga gugus gula dalam komponen glikon terlepas dan akhirnya komponen glikon berubah struktur menjadi komponen aglikon (nonpolar). Hidrolisis dapat dilakukan dengan cara merendam ekstrak kental hasil maserasi dengan $\mathrm{HCl} 2 \mathrm{~N}$ selama 2-3 jam. Penambahan asam kuat seperti $\mathrm{HCl}$ pada sistem reaksi hidrolisis akan berpengaruh terhadap kekuatan pelepasan proton $\left(\mathrm{H}^{+}\right)$ yang berpengaruh terhadap pemutusan ikatan glikosida (Handoko, 2006).

Berdasarkan beberapa hasil penelitian di atas, maka perlu dilakukan penelitian lebih lanjut mengenai aktivitas antibakteri ekstrak alga coklat jenis $S$. vulgare dengan adanya hidrolisis dan partisi. Pentingnya penelitian ini dikarenakan pada penelitian sebelumnya ditemukan potensi antibakteri dari alga coklat jenis $S$. vulgare. Penelitian ini akan dilakukan dengan metode ekstraksi maserasi dan hidrolisis kemudian dipartisi menggunakan variasi pelarut organik yaitu etil asetat, kloroform dan petroleum eter.

\section{METODE PENELITIAN Pelaksanaan Penelitian}

Penelitian ini dilaksanakan pada bulan Februari sampai dengan Mei 2014 di Laboratorium Kimia Organik dan Bioteknologi Jurusan Kimia Fakultas Sains dan Teknologi Universitas Islam Negeri (UIN) Maulana Malik Ibrahim Malang.

\section{Alat Dan Bahan}

Alat yang digunakan blender, gunting, pisau, oven, neraca analitik, seperangkat alat gelas, rotary evaporator vacumm, hot plate, magnetic stirer, spektrofotometer, spatula, gelas arloji, cawan petri, cawan penguap, tabung reaksi, kertas saring, kertas cakram, kapas, shaker, botol media, jarum ose, inkubator, pinset, autoklaf, bunsen, mikro pipet, plat KLT silika gel $\mathrm{F}_{254}$ dan penggaris.

Bahan yang digunakan dalam penelitian ini adalah alga coklat jenis Sargassum vulgare. Bahan kimia yang digunakan adalah metanol, etil asetat, kloroform, petroleum eter, $\mathrm{HCl} 2 \mathrm{~N}$, Nabikarbonat, standar glukosa, reagen DNS, reagen Dragendorf, reagen Mayer, serbuk logam $\mathrm{Mg}$, metanol $50 \%$, kloroform, $\mathrm{HCl}$ $2 \%, \mathrm{HCl} 1 \mathrm{~N}$, asam asetat anhidrat, larutan 
gelatin, asam sulfat pekat, nheksana,aseton dan reagen LiebermanBuchard. Uji antibakteri menggunakan bahan-bahan sebagai berikut: media nutrien agar padat (NA), media nutrient cair (NB), etanol, kertas saring Wathman, aquades steril, alumunium foil, biakan bakteri Staphylococcus aureus dan Escherichia coli, penisilin dan streptomisin.

\section{PROSEDUR PENELITIAN}

\section{Preparasi Sampel}

Alga coklat $S$. vulgare segar dicuci, kemudian dipotong kecil-kecil dan dikeringkan dalam oven pada suhu 37-38 ${ }^{\circ} \mathrm{C}$. Sampel yang telah kering dihaluskan menggunakan blender sampai diperoleh serbuk yang selanjutnya serbuk diayak menggunakan ayakan ukuran 60-100 mesh.

\section{Analisa Kadar Air}

Sebanyak 5 gram serbuk sampel pada cawan konstan dipanaskan dalam oven pada suhu 100-105 ${ }^{0} \mathrm{C}$ sekitar 15 menit. Cawan disimpan dalam desikator sekitar 10 menit selanjutnya ditimbang. Dilakukan pengulangan sampai diperoleh berat konstan.

\section{Analisa Kadar Garam}

Sebanyak 5 gram serbuk sampel diekstrak menggunakan aquades panas sebanyak $10 \mathrm{~mL}$ dan diaduk selama 10 menit. Ekstraksi diulangi sebanyak 10 kali. Kemudian filtrat diukur kadar garamnya menggunakan alat salinometer Atago PAL06S refraktometer.

\section{Ekstraksi}

Sebanyak 200 gram serbuk sampel diekstraksi menggunakan $600 \mathrm{~mL}$ metanol p.a dan diaduk menggunakan shaker selama 24 jam dengan kecepatan 120 rpm. Ekstraksi maserasi diulangi sebanyak 3 kali dan seluruh filtrat yang diperoleh selanjutnya digabung menjadi satu kemudian dipekatkan menggunakan rotary evaporatorvacuum sehingga diperoleh ekstrak pekat. Ekstrak pekat yang diperoleh selanjutnya dibagi menjadi dua bagian. Bagian I untuk diuji aktivitas antibakteri dan analisis gula reduksi (ekstrak metanol kasar) dan bagian II untuk dihidrolisis.

\section{Hidrolisis dan Partisi}

Hidrolisis dilakukan dengan cara menyiapkan 3 wadah, yaitu $\mathrm{A}, \mathrm{B}$ dan $\mathrm{C}$ kemudian masing-masing wadah diisi dengan ekstrak pekat sebanyak 7 gram. Kemudian setiap ekstrak ditambah $14 \mathrm{~mL}$ larutan $\mathrm{HCl} 2 \mathrm{~N}$ dan diaduk menggunakan magnetic stirer pada suhu ruang selama 1 jam. Hidrolisat yang diperoleh ditambahkan $\mathrm{NaHCO}_{3}$ sampai pHnya netral ( $\mathrm{pH}$ 7), kemudian dipartisi dengan variasi pelarut organik yaitu: etil asetat, kloroform dan petroleum eter masingmasing sebanyak $25 \mathrm{~mL}$. Dari hasil partisi akan diperoleh dua lapisan, lapisan organik digunakan untuk uji antibakteri dan identifikasi golongan senyawa sedangkan lapisan air digunakan untuk uji kadar gula reduksi.

\section{Uji Gula Reduksi Metode DNS}

Standar glukosa $10 \mathrm{ppm}$ diukur absorbansinya pada panjang gelombang 500-600 nm untuk mendapatkan panjang gelombang optimum. Kurva standar dibuat dengan mengukur absorbansi glukosa standar 10, 20,30,40 dan 50 ppm pada panjang gelombang optimum. Masingmasing lapisan air hasil partisi dan ekstrak pekat metanol sebelum dihidrolisis diambil $1 \mathrm{~mL}$ dan ditambahkan $1 \mathrm{~mL}$ reagen DNS. Kemudian larutan divorteks dan dipanaskan dalam air mendidih selama 15 menit. Dalam keadaan panas ditambah 1 $\mathrm{mL}$ larutan KNa-Tartrat dan ditandabataskan dalam labu ukur $10 \mathrm{~mL}$. Didinginkan hingga mencapai suhu ruang dan diukur absorbansinya dengan spektrofotometer pada panjang gelombang optimum. Nilai pengukuran yang diperoleh diplot ke dalam kurva standar.

\section{Uji Aktivitas Antibakteri}

Pengujian dengan metode difusi cakram. Kertas cakram $5 \mathrm{~mm}$ diresapkan pada masing-masing fraski dengan konsentrasi $10 \%, 7,5 \%, 5 \%, 2,5 \%, 1 \%$ dan $0,5 \%$. Kertas cakram yang 
mengandung ekstrak diletakkan di atas permukaan media agar padat yang telah ditanami dengan $0,1 \mathrm{~mL}$ biakan aktif bakteri. Diinkubasi selama 24 jam pada suhu $37^{\circ} \mathrm{C}$ dan diamati terbentuknya zona bening disekitar kertas cakram.

\section{Uji Fitokimia}

Fraksi pelarut yang memberikan aktivitas antibakteri tertinggi diuji golongan senyawanya dengan uji reagen (fitokimia).

\section{Alkaloid}

Ekstrak dimasukkan ke dalam tabung reaksi, ditambah $0,5 \mathrm{~mL} \mathrm{HCl} 2 \%$ dan larutan dibagi ke dalam dua tabung. Tabung I ditambahkan 2-3 tetes reagen Dragendorff, tabung II ditambahkan 2-3 tetes reagen Mayer. Jika tabung I terbentuk endapan jingga dan pada tabung II terbentuk endapan kekuning-kuningan, maka menunjukkan adanya alkaloid (Indrayani, dkk., 2006).

\section{Flavonoid}

Ekstrak dimasukkan ke dalam tabung reaksi kemudian dilarutkan dalam 1-2 mL metanol panas $50 \%$. Setelah itu ditambah serbuk logam $\mathrm{Mg}$ dan 4-5 tetes $\mathrm{HCl}$ pekat. Larutan berwarna merah atau jingga yang terbentuk menunjukkan adanya flavonoid (Indrayani, dkk., 2006).

\section{Saponin}

Ekstrak dimasukkan ke dalam tabung reaksi ditambah air (1:1) sambil dikocok selama 1 menit, apabila menimbulkan busa ditambahkan $\mathrm{HCl} 1 \mathrm{~N}$. Jika busa yang terbentuk dapat bertahan selama 10 menit dengan ketinggian 1-3 $\mathrm{cm}$, maka menunjukkan adanya golongan senyawa saponin.

\section{Triterpenoid}

Ekstrak dimasukkan ke dalam tabung reaksi, dilarutkan dalam $0,5 \mathrm{~mL}$ kloroform. Selanjutnya ditambahkan 0,5 $\mathrm{mL}$ asam asetat anhidrida. Kemudian, ditambahkan 1-2 mL larutan $\mathrm{H}_{2} \mathrm{SO}_{4}$ pekat melalui dinding tabung reaksi. Jika terbentuk cincin kecoklatan atau violet pada pembatas dua pelarut menunjukkan adanya golongan senyawa triterpenoid (Indrayani, dkk., 2006).

\section{Steroid}

Ekstrak dimasukkan ke dalam tabung reaksi, dilarutkan dalam $0,5 \mathrm{~mL}$ kloroform. Selanjutnya ditambahkan 0,5 $\mathrm{mL}$ asam asetat anhidrida. Kemudian ditambahkan 1-2 mL larutan $\mathrm{H}_{2} \mathrm{SO}_{4}$ pekat melalui dinding tabung reaksi. Jika terbentuk warna hijau kebiruan menunjukkan adanya golongan senyawa steroid (Indrayani, dkk., 2006).

\section{Tanin}

Uji tanin dilakukan dengan dua cara yaitu uji $\mathrm{FeCl}_{3}$ dan uji gelatin. Uji $\mathrm{FeCl}_{3}$ dilakukan dengan memasukkan ekstrak ke dalam tabung reaksi, kemudian ditambahkan dengan 2-3 tetes larutan $\mathrm{FeCl}_{3} 1 \%$. Jika larutan menghasilkan warna hijau kehitaman atau biru tinta, maka mengandung tanin.Uji gelatin dilakukandengan memasukkan ekstrak ke dalam tabung reaksi kemudian ditambah dengan larutan gelatin. Jika terbentuk endapan putih, menunjukkan adanya tanin

\section{Pemisahan Golongan Senyawa Aktif}

Pemisahan dengan kromatografi lapis tipis analitik dilakukan terhadap golongan senyawa yang dinyatakan positif dari hasil uji fitokimia melalui uji reagen. Pemisahan dengan kromatografi lapis tipis analitik dilakukan menggunakan plat silika gel $\mathrm{F}_{254}$.

\section{Analisa data}

Data yang diperoleh kemudian dianalisis dengan uji ANOVAdua arah untuk menguji adanya pengaruh antar perlakuan variasi konsentrasi dan variasi pelarut terhadap zona hambat yang dihasilkan. Apabila terdapat adanya pengaruh, maka dilanjutkan dengan uji beda nyata terkecil (BNT) dengan tingkat signifikansi $5 \%$ untuk mengetahui perlakuan yang berpengaruh atau berbeda nyata di antara perlakuan yang lain. 


\section{HASIL DAN PEMBAHASAN Preparasi Sampel}

Preparasi sampel meliputi pencucian, pengeringan, penghalusan dan pengayakan. Sampel dicuci sampai bersih menggunakan air mengalir untuk menghilangkan kotoran yang melekat. Pengeringan sampel bertujuan untuk menurunkan kadar air dan mempermudah proses penyimpanan sampel. Pengeringan dilakukan menggunakan oven pada suhu 35-38 ${ }^{\circ} \mathrm{C}$ untuk menghindari kerusakan atau hilangnya senyawa aktif yang diinginkan. Penghalusan dilakukan agar luas permukaan sampel semakin besar sehingga kontak sampel dengan pelarut semakin maksimal. Selain itu, penghalusan juga memungkinkan pecahnya sel-sel, sehingga mempermudah pengambilan senyawa aktif oleh pelarut. Setelah dilakukan penghalusan sampel diayak menggunakan ayakan dengan ukuran 60100 mesh.

\section{Analisa Kadar Air}

Prinsip analisis kadar air adalah adanya pemanasan dan penimbangan (Thermogravimetri) menggunakan oven pemanas pada temperatur $105{ }^{\circ} \mathrm{C}$ sampai diperoleh berat konstan. Selisih berat sampel antara sebelum dan sesudah pemanasan menunjukkan jumlah air yang terkandung dalam sampel. Berdasarkan penelitian diketahui bahwa kadar air pada sampelbasah S. vulgare sebesar 77,625\%, kadar air tersebut cukup tinggi karena sampel $S$. vulgare diambil dari habitat perairan. Sedangkan kadar air sampel setelah dikeringkan sebesar 9,352\%.

Hasil analisis kadar air sampel kering alga coklat $S$. vulgare menghasilkan nilai yang cukup baik karena kurang dari $10 \%$. Menurut Cahyono dkk. (2011) jika kadar air bahan lebih besar dari $10 \%$ maka akan tumbuh mikroorganisme dan mempengaruhi reaksi enzimatis sehingga mempercepat pembusukan sampel. Penentuan kadar air juga berpengaruh terhadap proses ekstraksi zat aktif. Kadar air yang rendah dapat mempermudah proses penarikan zat aktif dalam sampel karena pelarut mudah menembus dinding sel sampel tanpa adanya gangguan dari molekul air.

\section{Analisa Kadar Garam}

Penentuan kadar garam dilakukan untuk mengetahui kadar salinitas dari suatu sampel, karena beberapa mikroorganisme sensitif terhadap kadar salinitas yang tinggi. Analisis kadar garam ini dilakukan dengan Salinometer Atago PAL-O6S Refractometer. Prinsip alat ini adalah dengan memanfaatkan indeks bias cahaya untuk mengetahui tingkat salinitas dari sampel yang berupa cairan. Berdasarkan perhitungan diperoleh kadar garam sebesar $15,6 \%$. Menurut Hudaya dan Derajat (1980) kadar garam pada konsentrasi 10-15 $\%$ dapat membunuh sebagian besar jenis bakteri, kecuali bakteri jenis "halofilik" yaitu jenis bakteri yang tahan terhadap konsentrasi garam 26,6 \%. Bakteri E. coli dapat dihambat pertumbuhannya pada konsentrasi garam $13 \%$ sedangkan bakteri S. aureus dapat dihambat pertumbuhannya pada konsentrasi garam 15-20\%.

\section{Ekstraksi}

Ekstraksi maserasi dilakukan untuk mengambil atau mengekstrak zat aktif yang terkandung dalam sampel melalui perendaman. Adanya sistem perendaman ini maka pelarut akan menembus dinding sel dan masuk ke dalam sel yang mengandung zat aktif. Dengan demikian maka zat aktifnya akan larut dalam pelarut. Berdasarkan perhitungan, sebanyak 200 gram serbuk alga coklat $S$. vulgare diperoleh ekstrak pekat metanol sebanyak 29,654 gram dengan rendemen ekstrak metanol sebesar $14,8 \%$.

\section{Hidrolisis}

Tujuan dilakukan hidrolisis adalah untuk memisahkan glikon (gugus gula) dengan aglikon (senyawa metabolit sekunder) pada suatu senyawa glikosida. Dengan adanya pemutusan ikatan glikosida ini, maka senyawa metabolit sekunder yang diperoleh menjadi lebih maksimal. 
Dugaan reaksi pemutusan ikatan glikosida ditunjukkan pada Gambar 1:

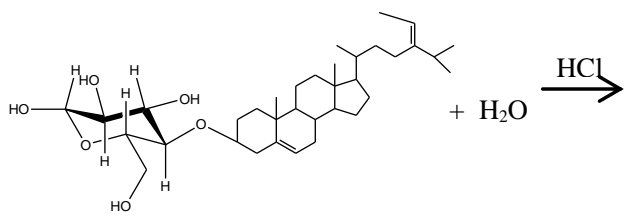

Senyawa glikosida

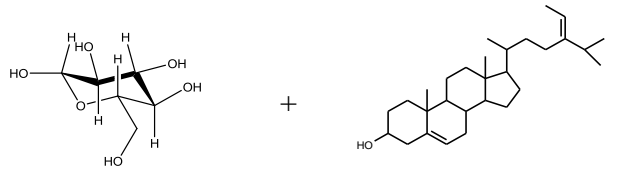

Glukosa (glikon) Fukosterol

Gambar 1 Dugaan reaksi hidrolisis

\begin{tabular}{lccc}
\multicolumn{4}{l}{ Tabel l.1 Hasil ekstraksi dan rendemen } \\
\hline Pelarut & Warna filtrat & Warna ekstrak pekat & Rendemen (\%) \\
\hline Etil asetat & Hijau kecoklatan & Coklat kehitaman & 26,3 \\
Kloroform & Hijau kehitaman & Hijau kehitaman & 27 \\
Petroleum eter & Coklat kehitaman & Coklat kehitaman & 25,3 \\
\hline
\end{tabular}

Berdasarkan Tabel 1.1, diketahui bahwa rendemen ekstrak fraksi kloroform lebih besar dari pada rendemen fraksi lainnya. Hasil rendemen ini diduga bahwa kandungan golongan senyawa yang bersifat semi polar dalam alga coklat $S$. vulgare lebih banyak dari pada senyawa polar dan non polar.

\section{Uji Gula Reduksi}

Setelah dilakukan hidrolisis, maka gugus gula (glikon) akan terputus dari ikatan glikosida. Glukosa dalam ekstrak akan bereaksi dengan reagen DNS dan ditunjukkan dengan perubahan warna. Intensitas warna yang terbentuk menunjukkan konsentrasi atau banyaknya gula yang mereduksi. Data yang diperoleh ditunjukkan dalam Tabel 2.

Tabel 2 Kadar gula reduksi ekstrak methanol tiap fraksi

\begin{tabular}{cc}
\hline Sampel & $\begin{array}{c}\text { Gula reduksi } \\
\text { (ppm) }\end{array}$ \\
\hline Ekstrak metanol & 26,1 \\
etilasetat & 11,3 \\
Kloroform & 16,4 \\
Etroleum eter & 13,8 \\
\hline
\end{tabular}

\section{Partisi (Ekstraksi cair-cair)}

Tujuan dari partisi ini adalah untuk melarutkan senyawa metabolit sekunder yang terkandung dalam ekstrak berdasarkan sifat kepolaran masingmasing. Prinsip ekstraksi cair-cair (partisi) yaitu proses pemisahan berdasarkan distribusi suatu zat diantara dua larutan yang tidak saling bercampur. Hasil ekstraksi dan rendemen masing-masing fraksi sebagaimana Tabel 1.

Berdasarkan Tabel 2, diketahui bahwa ekstrak kasar metanol sebelum dihidrolisis mempunyai kadar gula reduksi lebih tinggi dibandingkan dengan masingmasing lapisan air hasil hidrolisis. Hal tersebut dimungkinkan karena gugus gula yang berada dalam lapisan (fase) air hasil hidrolisis merupakan gula nonreduksi sehingga tidak dapat dideteksi dengan metode DNS. Hidrolisis yang kurangsempurna juga mempengaruhi pemutusan ikatan glikosida yang mengakibatkan glikon masih terikat pada aglikonnya. Dengan demikian, maka jumlah gula reduksinya telah tidak dapat terdeteksi.

\section{Uji Aktivitas Antibakteri}

Prinsip metode difusi cakram dalam pengujian antibakteri adalah terdifusinya zat antibakteri yang berada pada kertas cakram menuju permukaan media agar yang telah diinokulasi atau ditanami bakteri uji. Bakteri akan terhambat pertumbuhannya dengan pengamatan terbentuknya zona bening disekeliling kertas cakram. Hasil uji aktivitas antibakteri ekstrak kasar metanol, fraksi etil asetat, kloroform dan petroleum eter ditunjukkan pada Tabel 1 dan Tabel 2 .

Berdasarkan hasil uji aktivitas antibakteri pada Tabel 3 dan Tabel 4 diketahui bahwa aktivitas antibakteri yang baik diberikan oleh fraksi etil asetat. Dalam fraksi etil asetat dimungkinkan senyawa yang terkandung adalah golongan senyawa yang bersifat semipolar. Kemampuan fraksi etil asetat dalam 
menghambat pertumbuhan bakteri $E$. coli semakin besar dengan bertambahnya konsentrasi ekstrak. Hal ini disebabkan oleh kuantitas komponen aktif yang bersifat antibakteri akan semakin banyak dalam konsentrasi ekstrak yang kebih tinggi.

Tabel 3 Hasil uji aktivitas antibakteri ekstrak terhadap bakteri S. aureus

\begin{tabular}{|c|c|c|c|c|}
\hline \multirow[b]{2}{*}{ Konsentrasi (\%) } & \multicolumn{4}{|c|}{ Zona hambat (mm) } \\
\hline & $\begin{array}{c}\text { Ekstrak } \\
\text { Kasar } \\
\text { Metanol }\end{array}$ & $\begin{array}{c}\text { Fraksi } \\
\text { Etil } \\
\text { Asetat }\end{array}$ & $\begin{array}{c}\text { Fraksi } \\
\text { Kloroform }\end{array}$ & $\begin{array}{r}\text { Fraksi } \\
\text { Petroleum } \\
\text { Eter } \\
\end{array}$ \\
\hline 0,5 & - & - & - & - \\
\hline 1 & - & 1 & - & - \\
\hline 2,5 & - & 3,67 & - & - \\
\hline 5 & 0,5 & 4 & - & - \\
\hline 7,5 & 1,67 & 4,5 & - & - \\
\hline 10 & - & 8,5 & - & 1,5 \\
\hline $\begin{array}{r}\text { Kontrol positif } \\
\text { (penisilin 2,5) }\end{array}$ & \multirow{2}{*}{\multicolumn{4}{|c|}{25}} \\
\hline $\begin{array}{r}\text { Kontrol negatif } \\
\text { (pelarut) }\end{array}$ & & & & \\
\hline $\begin{array}{c}\text { Total bakteri } \\
\text { CFU/mL }\end{array}$ & \multicolumn{4}{|c|}{$2,88 \times 10^{8}$} \\
\hline
\end{tabular}

Tabel 4 Hasil uji aktivitas antibakteri terhadap bakteri E. coli

\begin{tabular}{ccccc}
\hline & \multicolumn{5}{c}{ Zona hambat (mm) } \\
\cline { 2 - 5 } Konsentrasi (\%) & $\begin{array}{c}\text { Ekstrak } \\
\text { Metanol } \\
\text { Kasar }\end{array}$ & $\begin{array}{c}\text { Fraksi } \\
\text { Etil } \\
\text { Asetat }\end{array}$ & $\begin{array}{c}\text { Fraksi } \\
\text { Kloroform }\end{array}$ & $\begin{array}{c}\text { Fraksi } \\
\text { Petroleum } \\
\text { Eter }\end{array}$ \\
\hline 0,5 & - & - & - & - \\
1 & - & - & - & - \\
2,5 & - & 0,83 & - & - \\
5 & - & 2,17 & - & - \\
7,5 & - & 5,17 & - & - \\
10 & - & 6 & - & - \\
Kontrol positif & & & 13,5 & - \\
(Streptomisin 0,6) & & & & - \\
Kontrol negatif \\
(pelarut)
\end{tabular}

Aktivitas antibakteri pada ekstrak semipolar juga ditunjukkan pada penelitian Eom et al. (2011) yang mengekstrak alga coklat Eisenia bisiklis dengan pelarut metanol kemudian dipartisi menggunakan variasi pelarut $n$-heksana, diklorometana, etil asetat dan $n$-butanol. Berdasarkan penelitian tersebut, fraksi etil asetat mempunyai aktivitas dalam menghambat pertumbuhan bakteri $S$. aureus dengan aktivitas yang paling besar. Didukung oleh penelitian Reveny (2011) yang menginformasikan bahwa fraksi etil asetat memberikan aktivitas antibakteri terbaik terhadap bakteri S. aureus dan E. coli. 
Fraksi etil asetat menunjukkan aktivitas antibakteri yang cenderung lebih kecil dibandingkan dengan senyawa dalam obat komersil seperti penisilin dan streptomisin. Pada penelitian ini digunakan kontrol positif yaitu penisilin untuk bakteri S. aureus dengan zona hambat 25 mmdan streptomisin untuk bakteri E. coli dengan zona hambat 13,5 mm. Menurut Davis dan Stout (1971) dalam Yuningsih (2007) daerah hambatan ekstrak kurang dari $5 \mathrm{~mm}$ tergolong lemah, antara $5 \mathrm{~mm}$ sampai 8 $\mathrm{mm}$ tergolong lemah, antara 10 sampai 20 $\mathrm{mm}$ tergolong kuat dan lebih dari $20 \mathrm{~mm}$ tergolong sangat kuat. Berdasarkan pengujian aktivitas antibakteri menghasilkan zona hambat terbaik yaitu $8,5 \mathrm{~mm}$ terhadap bakteri $S$. aureus dan 6 mm terhadap E. coli. Jika dimasukkan ke dalam rentang ketentuan kekuatan antibakeri, maka aktivitas antibakteri yang diberikan oleh fraksi etil asetat alga coklat $S$. vulgare tergolong sedang.

Kontrol negatif yang digunakan adalah pelarut dan dari hasil pengujian diketahui bahwa kontrol negatif tidak memberikan daya hambat terhadap kedua bakteri uji. Sehingga dapat disimpulkan bahwa zona hambat ekstrak yang terbentuk adalah murni dari aktivitas ekstrak dan tidak dipengaruhi oleh pelarut yang digunakan. Selain itu, berdasarkan analisis kadar garam terhadap sampel diketahui bahwa kadar salinitas sampel juga tidak memberikan pengaruh terhadap penghambatan bakteri uji. Terhambatnya pertumbuhan bakteri uji cenderung disebabkan oleh senyawa aktif yang terkandung dalam ekstrak $S$. vulgare.

Bakteri $S$. aureus cenderung dapat dihambat oleh konsentrasi ekstrak yang lebih rendah dibandingkan dengan bakteri E. coli. Hal tersebut diduga karena adanya perbedaan komponen penyusun dinding sel bakteri gram positif ( $S$. aureus) dan gram negatif (E. coli). Dinding sel bakteri gram positif mengandung lipid yang lebih rendah daripada bakteri gram negatif (Pelczar dan Chan, 1986). Diduga komponen senyawa aktif yang bersifat semipolar cenderung lebih mudah masuk ke dalam dinding sel bakteri gram positif dalam menghambat pertumbuhannya.

\section{Uji Fitokimia}

Fraksi $S$. vulgare yang mempunyai aktivitas antibakteri tertinggi selanjutnya dilakukan uji fitokimia. Berdasarkan penelitian dan pengamatan diperoleh hasil uji fitokimia fraksi etil asetat $S$. vulgare sebagaimana pada Tabel 5 .

Tabel 5 Hasil uji fitokimia fraksi etil asetat alga coklat $S$. vulgare

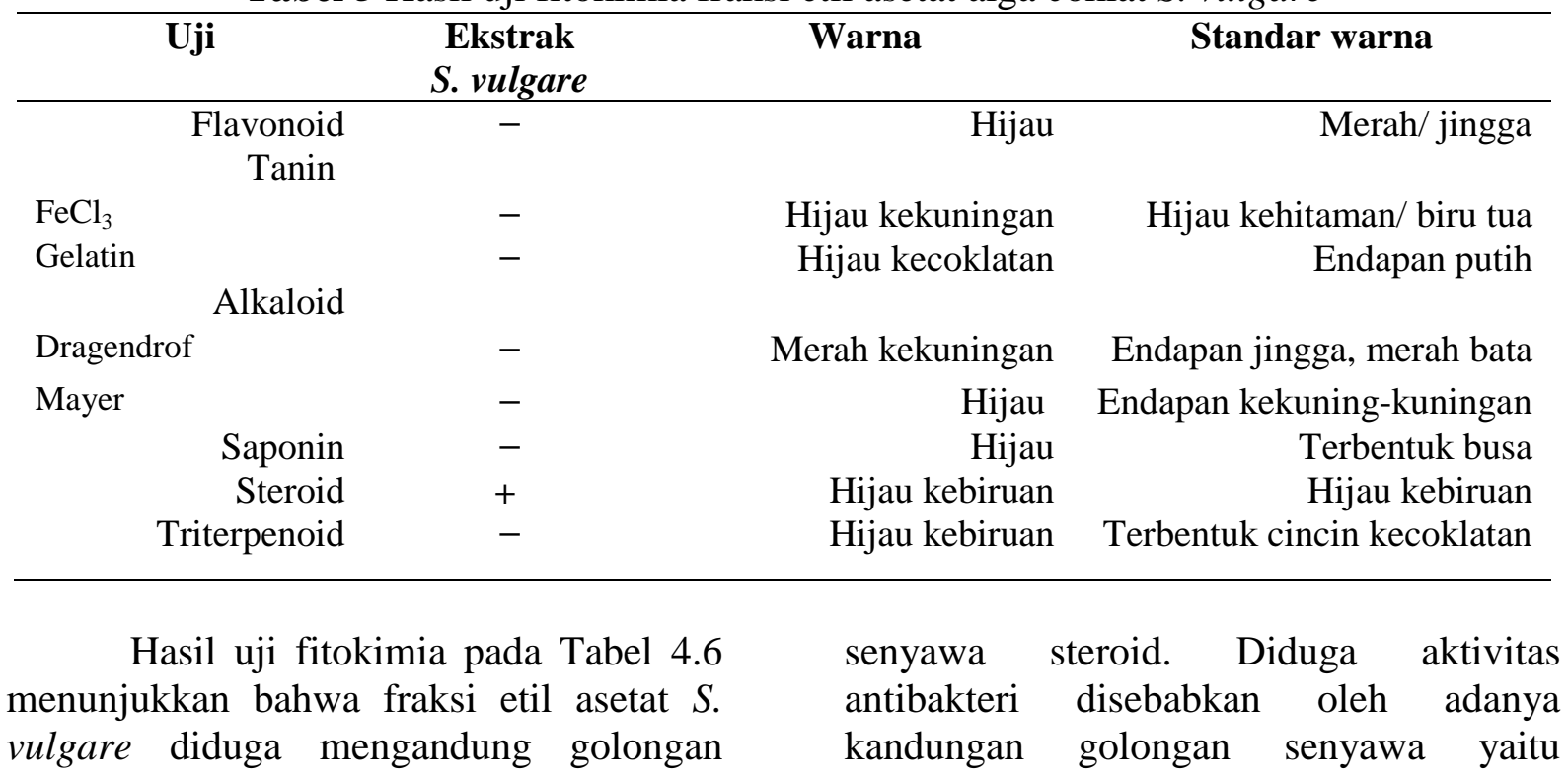


steroid. Hal ini sesuai dengan pendapat Farouk et al. (2007) yang menyatakan bahwa metabolit sekunder yang berpotensi sebagai senyawa antimikroba adalah golongan atau turunan dari senyawa terpenoid, diantaranya yaitu steroid. Golongan steroid menghambat pertumbuhan bakteri dengan cara mengganggu proses pembentukan membran dan dinding sel bakteri. Pada keadaan tersebut fosfolipid yang merupakan lapisan tipis yang menyelimuti peptidoglikan tidak mampu mempertahankan bentuk membran sitoplasma. Akibatnya, membran sitoplasma akan mengalami lisis dan bakteri akan mengalami hambatan pertumbuhan bahkan kematian (Robinson, 1995). Didukung oleh penelitian Morin dan Gorman (1995) yang menyebutkan bahwa senyawa steroid mempunyai struktur lipofilik yang akan berinteraksi dengan fosfolipid pada membran sel bakteri. Adanya reaksi ini menyebabkan integritas membran menurun dan morfologi membran berubah yang mengakibatkan rapuhnya membran sel bakteri dan sel mengalami lisis.

\section{Pemisahan Golongan Senyawa dengan KLTA}

Pemisahan golongan senyawa steroid menggunakan larutan pengembang campuran yaitu $n$-heksana : etil asetat (8:2). Hasil pemisahan golongan senyawa steroid pada fraksi etil asetat $S$. vulgare pada Tabel 6.

Tabel 6 Hasil pemisahan golongan senyawa steroid

\begin{tabular}{|c|c|c|c|c|}
\hline \multirow[b]{2}{*}{ No } & \multirow[b]{2}{*}{$\begin{array}{c}\text { Rf } \\
(\mathbf{c m})\end{array}$} & \multicolumn{2}{|c|}{$\begin{array}{l}\text { Warna noda di bawah sinar UV pada } \lambda \\
366 \mathrm{~nm}\end{array}$} & \multirow{2}{*}{$\begin{array}{l}\text { Dugaan } \\
\text { Senyawa }\end{array}$} \\
\hline & & $\begin{array}{l}\text { Sebelum disemprot } \\
\text { reagen Lieberman- } \\
\text { Buchard }\end{array}$ & $\begin{array}{l}\text { Setelah disemprot } \\
\text { reagen Lieberman- } \\
\text { Buchard }\end{array}$ & \\
\hline 1 & 0,05 & Merah muda & Merah muda & - \\
\hline 2 & 0,11 & Kuning & Merah muda & - \\
\hline 3 & 0,25 & - & Ungu & Steroid \\
\hline 4 & 0,32 & Ungu & Merah muda & - \\
\hline 5 & 0,38 & Merah muda & Ungu & Steroid \\
\hline 6 & 0,53 & Merah muda & Ungu & Steroid \\
\hline 7 & 0,58 & Merah muda & Ungu & Steroid \\
\hline 8 & 0,62 & Merah muda & Merah muda & - \\
\hline 9 & 0,68 & $\begin{array}{l}\text { Merah muda tengah } \\
\text { ungu }\end{array}$ & $\begin{array}{l}\text { Merah muda tengah } \\
\text { ungu }\end{array}$ & Steroid \\
\hline 10 & 0,81 & $\begin{array}{l}\text { Merah muda tengah } \\
\text { ungu }\end{array}$ & $\begin{array}{l}\text { Merah muda tengah } \\
\text { ungu }\end{array}$ & Steroid \\
\hline 11 & 0,91 & Merah muda & Merah muda & - \\
\hline
\end{tabular}

Identifikasi spot yang merupakan golongan senyawa steroid diperoleh sebanyak 6 spot. Spot ke 3, 5, 6, 7, 9 dan 10 dinyatakan positif golongan senyawa steroid yang ditunjukkan dengan terbentuknya warna ungu setelah disemprot dengan reagen Lieberman-Buchard dan dideteksi di bawah sinar UV366. Identifikasi golongan senyawa steroid setelah disemprot dengan reagen
Lieberman-Buchard dan dideteksi di bawah sinar UV366 akan menghasilkan warna spot di antaranya hijau, biru, ungu, coklat dan ungu.

\section{Analisis Data}

Berdasarkan analisis statistika diketahui bahwa perlakuan variasi konsentrasi terhadap bakteri S. aureus dan E. coli diperoleh $\mathrm{F}_{\text {hitung }}<\mathrm{F}_{\text {tabel }}$.Dengan demikian maka $\mathrm{H}_{0}$ diterima yang berarti 
perlakuan variasi konsentrasi ekstrak tidak berpengaruh nyata. Sedang pengambilan keputusan untuk perlakuan variasi pelarut terhadap bakteri $S$. aureus dan E. coli diperoleh $F_{\text {hitung }}>F_{\text {tabel }}$. Dengan demikian maka $\mathrm{H}_{0}$ ditolak dan $\mathrm{H}_{1}$ diterima, yang berarti perlakuan variasi pelarut berpengaruh nyata.

Berdasarkan uji beda nyata terkecil diketahui bahwa rata-rata zona hambat $S$. aureus terhadap perlakuan variasi pelarut metanol, kloroform dan petroleum eter tidak berbeda secara signifikan. Sedangkan pelarut etil asetat merupakan pelarut yang lebih baik jika direkomendasikan sebagai pelarut untuk mengekstraksi golongan senyawa yang berpotensi sebagai obat antibakteri.

\section{KESIMPULAN DAN SARAN}

Hasil hidrolisis ekstrak metanol alga coklat $S$. vulgareyang mempunyai aktivitas antibakteri tertinggi adalah fraksi etil asetat dengan zona hambat $8,5 \mathrm{~mm}$ terhadap bakteri $S$. aureus dan $6 \mathrm{~mm}$ terhadap bakteri $e$. coli. Golongan senyawa yang terdapat dalam fraksi etil asetat alga coklat $S$. vulgarediduga golongan senyawa steroid. Saran

Sebaiknya pengujian kadar garam dilakukan pada ekstrak hasil maserasi, untuk mengetahui kadar garam yang terkandung dalam ekstrak setelah dilakukan ekstraksi. Ekstraksi menggunakan variasi pelarut organik lain perlu dilakukan untuk mengetahui aktivitas ekstrak dalam pelarut yang berbeda. Perlu dilakukan pengujian aktivitas antibakteri dengan penggunaan bakteri uji dan metode uji yang lain, seperti metode dilusi cair.

\section{DAFTAR PUSTAKA}

Alamsjah, M.A., Nurhayati, D. dan Thahjaningsih, W. 2011. Pengaruh Ekstrak Alga Cokelat (Sargassum $s p$.) terhadap Pertumbuhan Bakteri Escherechia coli Secara In Vitro. Jurnal Ilmiah Perikanan dan Kelautan, Vol.3,No.1.
Alfiyaturohmah. 2013. Uji Aktivitas Antibakteri Ekstrak Kasar Etanol, Klorofom dan $n$-heksana Alga Coklat Sargassum vulgare Asal Pantai Kapong Pamekasan Terhadap Bakteri S. aureus dan E. coli. Tugas Akhir Tidak Diterbitkan. Malang: UIN Maulana Malik Ibrahim Malang.

Bachtiar, S.Y., Tjahjaningsih, W. dan Sianita, N. 2012. Pengaruh Ekstrak Alga Coklat (Sargassum sp.) Terhadap Pertumbuhan Bakteri Escherichia coli. Jurnal of Marine and Coastal Science, Vol.1, No.1, 53-60.

Cahyono, B., Huda, M.D.K. dan Limantara,

L. 2011. Pengaruh Proses

Pengeringan Rimpang Temulawak (Curcuma xanthorriza ROXB) Tehadap Kandungan Dan Komposisi Kurkuminoid. Reaktor, Vol.13, No.3.

Eom, et al. 2011. Antimicrobial Activity of Brown Alga Eisenia bicylics against Methicillin-resistant Staphylococcus aureus. Fish Aquat Sci. Vol.14, No.4.

Farouk, A.E., Faizal A.H.G. dan Ridzwan B.H. 2007. New Bacterial Species Isolated from Malaysian Sea Cucumbers with Optimized Secreted Antibacterial Activity. American Journal of Biochemistry and Biotechnology.

Handoko, S.P. 2006. Kinetika Hidrolisis Maltosa Pada Variasi Suhu dan Jenis Asam Sebagai Katalis. Sigma, Vol. 9, No. 1: 9-17.

Hudaya, S. dan Derajat, S. 1980. DasarDasar Pengawetan I. Jakarta: Departemen Pendidikan dan Kebudayaan.

Indrayani, L., Soetjipto, H. dan Sihasale, L. 2006. Skrinning Fitokimia dan Uji Toksisitas Ekstrak Daun Pecut Kuda (Stachytarpheta jamaicensis $L$. Vahl) Terhadap Larva Udang Artemia salina Leach. Jurnal Fakultas Sains dan Matematika. 
Salatiga: Universitas Kristen Satya Wacana.

Jawetz, E., Adelberg E.A. dan Melniek J. 1996. Mikrobiologi Kedokteran. Terjemahan Edi Nugroho dan Maulana R.F. Jakarta: Kedokteran EGC.

Miftahurrahmah. 2012. Ekstraksi, Uji Aktivitas Antibakteri dan Identifikasi Golongan Senyawa Aktif Alga Merah Eucheuma spinosum Dari Pesisir Laut Banyuwangi. Skripsi Tidak Diterbitkan. Malang: UIN Maulana Malik Ibrahim Malang.

Morin, R.B dan Gorman, M. 1995. Kimia dan Biologi Antibiotik $\beta$-lactam Edisi III. Semarang: IKIP Semarang Press.

Muhimmah, A.A. 2013. Aktivitas Antibakteri Ekstrak Metanol Dan $N$ Heksana Rumput Laut Merah (Eucheuma cottonii) Pesisir Pantai Lobuk Madura Terhadap Bakteri Escherichia coli dan Staphylcoccus aureus. Skripsi Tidak Diterbitkan.
Malang: UIN Maulana Malik Ibrahim Malang.

Pelczar, M.J. dan Chan, E.C.S. 1986. Dasar-Dasar Mikrobiologi. Jilid 1. Alih Bahasa: Hadioetomo, R. S., Imas, T., Tjitrosomo, S.S., dan Angka, S.L., Jakarta: UI Press.

Reveny, J. 2011. Daya Antimikroba Ekstrak dan Fraksi Daun Sirih Merah (Piper betle Linn.). JurnalImu Dasar. Vol. 12, No.1.

Robinson, T. 1995. Kandungan Organik Tumbuhan Tingkat Tinggi. Penerjemah: Kosasih Padmawinata. Bandung: ITB Press.

Tensiska, Marsetio dan Yudiastuti, S.O.N 2007. Pengaruh Jenis Pelarut Terhadap Aktivitas Antioksidan Ekstrak Kasar Isoflavon Dari Ampas Tahu.Hasil Penelitian.Bandung: Universitas Padjadjaran.

Yuningsih, R. 2007. Aktivitas Antibakteri Ekstrak Daun Jawer Kotok (Coleus scutellarioides [L.] Benth.). Skripsi Tidak Diterbitkan. Bogor: Institut Pertanian Bogor. 